\title{
The Newly Adopted Hague Judgments Convention: A Missed Opportunity for Intellectual Property
}

\author{
Lydia Lundstedt
}

Published online: 30 August 2019

(C) Max Planck Institute for Innovation and Competition, Munich 2019

The architecture of the internet requires cooperation within the international community for the effective enforcement of intellectual property (IP) rights. Thus, it was with great interest that the IP community followed the 22nd Diplomatic Session of the Hague Conference on Private International Law from 18 June to 2 July 2019 when the Members met to finalize and adopt what is now the 2019 Convention on the Recognition and Enforcement of Foreign Judgments in Civil or Commercial Matters ("The Judgments Convention"). ${ }^{1}$ This achievement culminates a long journey that started with the failed 1999 Draft Convention on Jurisdiction and the Enforcement of Judgments ${ }^{2}$ and its 2001 interim text, ${ }^{3}$ to the successful half-way milestone of the 2005 Convention on Choice of Court Agreements. ${ }^{4}$

The main objective of the Judgments Convention is to ensure that a judgment given in one Contracting State (State of origin) which falls within the Convention's

\footnotetext{
${ }^{1}$ Convention of 2 July 2019 on the Recognition and Enforcement of Foreign Judgments in Civil or Commercial Matters (not yet in force), https://www.hcch.net/en/instruments/conventions/full-text/?cid= 137.

2 Preliminary Draft Convention on Jurisdiction and Foreign Judgments in Civil and Commercial Matters (adopted by the Special Commission on 30 October 1999), https://assets.hcch.net/upload/wop/jdgmpd11. pdf.

3 Summary of the Outcome of the Discussion in Commission II of the First Part of the Diplomatic Conference 6-20 June 2001, Interim Text, prepared by the Permanent Bureau and the Co-reporters, https://assets.hcch.net/upload/wop/jdgm2001draft_e.pdf.

${ }^{4}$ Convention of 30 June 2005 on Choice of Court Agreements (entered into force 1 October 2015), https://assets.hcch.net/docs/510bc238-7318-47ed-9ed5-e0972510d98b.pdf.
}

L. Lundstedt $(\bowtie)$

Dr. jur.; Senior Lecturer in Private International Law, Law Department, Stockholm University,

Stockholm, Sweden

e-mail: Lydia.Lundstedt@juridicum.su.se

L. Lundstedt

Senior Lecturer in Intellectual Property Law, Commercial and Business Law Division, Department of Management and Engineering, Linköping University, Linköping, Sweden 
scope of application is recognized and enforced in another Contracting State (requested State), thereby enhancing "practical" access to justice and facilitating cross-border trade and investment. In light of the importance of IP to European and global markets, the European Union (EU) had initially advocated the understandable position that IP judgments be fully included in the scope of the Convention. However, throughout the drafting process, the treatment of IP judgments proved to be a contentious issue.

In an effort to salvage the Judgments Convention's application to at least some IP judgments, the EU subsequently introduced a proposal to narrow the scope to only copyright and related rights and leave industrial property rights outside the Convention's scope. After intense deliberations, however, the delegates were unable to reach a consensus on the treatment of IP judgments or even on copyright and related rights judgments. Consequently, IP judgments were fully excluded from the scope of the Judgments Convention. The decision to exclude IP judgments from the scope of the Judgments Convention must be seen as a missed opportunity for the IP Community and for the international community at large.

Pursuant to the Judgments Convention, a judgment is to be recognized and enforced by the other Contracting States if it complies with one of the jurisdictional filters made up of internationally accepted bases for jurisdiction (e.g. a defendant's habitual residence), unless a ground for refusal set out in the Convention applies (e.g. ordre public). The Judgments Convention does not prevent the requested State from recognizing and enforcing judgments under its national law even though the judgment does not comply with one of the Convention's jurisdictional filters, except where the judgment is subject to an exclusive jurisdictional filter. ${ }^{5}$ Judgments that comply with an exclusive jurisdictional filter must be recognized and enforced, and judgments that do not, must not be recognized or enforced even under national law.

Under the 2018 draft that formed the basis for the discussions at the Diplomatic Session, judgments ruling on IP rights would have been subject to a separate, more restrictive regime for recognition and enforcement based on a strict application of the territoriality principle:

- IP judgments would have been eligible for recognition and enforcement under the Convention only if the judgment was given by a court in a Contracting State where the IP right was registered and/or protected;

- judgments that ruled on the validity of a registered IP right would have been subject to an exclusive jurisdictional filter;

- judgments ruling on the infringement of an IP right would have been eligible for recognition and enforcement only if the court ruled on an infringement in its own territory;

- an infringement judgment would not be eligible for recognition and enforcement if the defendant had not acted in the State of origin to initiate or further the

\footnotetext{
5 The Judgments Convention has only one exclusive jurisdictional filter, which is for judgments that ruled on rights in rem in immovable property. See Art. 6 Judgments Convention.
} 
infringement, or the defendant's activity could not reasonably have been seen as targeting the State of origin;

- recognition and enforcement could still be refused if the court in the State of origin failed to apply the lex protectionis, which would be its own domestic law.

Notwithstanding all these safeguards aiming to preserve the principle of territoriality, IP judgments were ultimately excluded from the scope of the Judgments Convention.

It is difficult to understand the resistance by some delegates (and some IP stakeholders) to including IP judgments within the scope of the Judgments Convention. The inclusion of IP judgments would have ensured that a right holder had access to "practical" justice by obligating the Contracting States to recognize and enforce IP judgments handed down by a court in the country where the IP right was protected/registered assuming that country is a Contracting State. It should be recalled that the country of protection/registration is in many cases the most appropriate forum to adjudicate an infringement of an IP right. In fact, due to the principle of territoriality that some States observe at the level of jurisdiction, the country of protection/registration may be the only State willing to exercise jurisdiction over the claim. ${ }^{6}$

An obligation to recognize and enforce judgments handed down by the country of protection/registration was not necessary before the advent of the internet. Indeed, a trader could hardly conduct business and have the potential to infringe IP rights in another country if it did not have some physical presence in that country against which a local judgment could be enforced. The problem today is that the internet allows traders to conduct business and infringe IP rights in another country without the need to maintain any physical presence there. Thanks to the internet, traders can market and sell their goods directly to consumers in other countries. Moreover, as it is becoming more common for digital goods to replace their physical counterpart, it is less likely that anything exists in the country of protection/ registration that can be seized.

Excluding IP judgments from the scope of the Judgment Convention is a missed opportunity for the IP community and the international community at large. Including IP judgments in the scope of the Convention would have provided right holders with an effective means to enforce their rights as opposed to merely obtaining a worthless piece of paper recording the decision of the court in the country of registration/protection. Moreover, it would have fortified a basic premise of the territoriality principle: the right of each sovereign State to use domestic IP rights as an instrument to achieve its own economic, social and cultural policies within its own territory. Lastly, the proposal to include IP judgments within the scope of the Judgments Convention would have imposed a modest obligation, yet a

\footnotetext{
6 See Gallo Africa Ltd v. Sting Music (Pty) Ltd (40/2010) [2010] ZASCA 96; 2010 (6) SA 329 (SCA); [2011] 1 All SA 449 (SCA) (South Africa: Supreme Court of Appeal 3 September 2010) holding that South Africa did not have jurisdiction to adjudicate foreign copyright infringement claims; Voda, M.D. v. Cordis Corp., 476 F.3d 887 (Fed. Cir. 2007) (United States) holding that the United States did not have jurisdiction over foreign patent infringement claims.
} 
significant first step toward developing trust and facilitating further cooperation within the IP community in cross-border dealings. ${ }^{7}$

Looking forward, however, the Diplomatic Session invited "the Council on General Affairs and Policy to consider, at its 2020 meeting, what, if any, further work it wishes the $\mathrm{HCCH}$ to undertake on the intersection between private international law and intellectual property". This opening was recorded in the Final Act of the Judgments Convention. Let us hope that if there is a next time, the Members of the Hague Conference will not miss this opportunity again.

Publisher's Note Springer Nature remains neutral with regard to jurisdictional claims in published maps and institutional affiliations.

\footnotetext{
${ }_{7}$ There is an increasing wealth of soft law instruments on the intersection of IP law and private international law that could serve as a basis for further cooperation. See e.g. the European Max Planck Group, "Principles on Conflict of Laws in Intellectual Property", https://www.ip.mpg.de/fileadmin/ ipmpg/content/clip/Final_Text_1_December_2011.pdf; the American Law Institute, "Intellectual Property: Principles Governing Jurisdiction, Choice of Law, and Judgments in Transnational Disputes", http:// www.wipo.int/wipolex/en/details.jsp?id=7687; the International Law Association, "Draft Guidelines: Intellectual Property in Private International Law", 22 May 2018, http://www.ila-hq.org/index.php/ committees.
} 